\title{
The Default Risk of China's Credit Market from the Perspective of Industries
}

\author{
Qi Yu' ${ }^{1}$, Fangbin $\mathrm{Xu}^{2}$, Jiuyan Cao ${ }^{1}$ \\ ${ }^{1}$ School of Economics in Northeastern University at Qinhuangdao \\ ${ }^{2}$ School of Control Engineering in Northeastern University at Qinhuangdao \\ Taishang Road No.143, Economic technology and development district, Qinhuangdao, China
}

Keywords: Credit Market; Industry Structure

Abstract: Nowadays, the credit industry of China's commercial banks is highly concentrated in industries such as manufacturing, wholesale and retail, which have high non-performing loan rates and low credit asset quality, leading to poor overall credit asset quality of commercial banks. Optimizing the industrial structure of commercial bank credit can effectively improve the quality of commercial bank assets. This paper evaluates the industrial structure of China's credit market from the perspective of industry, and proposes recommendations for the credit funds of different industries based on industry evaluation.

\section{Introduction}

Market experience believes that changes in non-performing loan ratios usually lag behind economic operations, and the previous economic data is confirmed by existing statistics. According to Eastern Assets, the main source of bank non-performing loans in 2017 is manufacturing. According to the data of 10 listed banks that disclose non-performing loan ratios by industry, the non-performing loans of manufacturing industry in 2016 were about 300 billion yuan, and the non-performing loans of wholesale and retail businesses were about 2300. With a trillion yuan, the current industrial restructuring is deepening, and the credit risk of overcapacity industries will gradually emerge. This paper selects industries such as manufacturing, wholesale and retail, real estate, transportation, warehousing and postal industries from relatively low and relatively low default rates, trying to present them through the characteristics of the industry itself and non-performing loan ratios. The characteristics of the industry indicate the relative risk of high or low in the industry.

\section{Industry Analysis}

\subsection{Manufacturing}

As of December 31, 2015, the balance of non-performing assets of the manufacturing industry in commercial banks was 429.82 billion yuan, ranking the top non-performing loan ratio of 3.35\%. Manufacturing is a pillar industry of the country and is inextricably linked to the development of the national economy. In order to promote the development of the manufacturing industry, the State 
Council announced the "China Manufacturing 2025" strategic plan in May 2015, and strive to achieve the goal of China's manufacturing powerhouse. As an investment-driven industry, the development of the manufacturing industry faces numerous difficulties. During the crucial period of the country's macroeconomic downturn and industrial restructuring, the manufacturing industry is facing many challenges. The growth rate is slowing down, internal demand is insufficient, and the industry's credit risk is increasing. The default rate increases year by year. China's manufacturing industry generally lacks core competitiveness, slow transformation and upgrading, and financing difficulties, leading to deterioration of business operations, which in turn leads to a high level of credit risk. In addition, its scale accounts for a large proportion of bank loans, and the credit conditions of manufacturing industries are The influence of commercial banks is self-evident. The long-standing high default rate in the industry has caused banks to reduce their credit supply to the manufacturing industry as much as possible.

In addition, the construction industry and the mining industry, which are highly related to the manufacturing industry, have also been affected. The overall industry-wide credit risk has increased. This poses a great threat to the stability of China's commercial bank credit system. The polarization of the manufacturing industry is increasingly widening, and technology-oriented, energy-saving, and environmental-friendly industries are increasingly emerging. Eliminating outdated enterprises and integrating quality resources are inevitable. For manufacturing enterprises that have loans, commercial banks should refer to national policy guidance for reasonable screening, and raise the loan threshold for high energy-consuming and highly polluting enterprises. In terms of macroeconomic policies, we must speed up industrial transformation and promote technological innovation, improve the core competitiveness of China's industries, and expand related financing at the same time so as to fundamentally promote the healthy development of the manufacturing industry and related industries.

\subsection{Wholesale and Retail Trade}

As of the end of 2015, the balance of non-performing assets of wholesale and retail trade in commercial banks was 399.77 billion yuan, and the non-performing loan ratio was the highest in the industry, about $4.25 \%$. The connection of production and consumption in the wholesale and retail industry is an important medium for realizing the value of the products of various industrial sectors of the society and an important part of the circulation of commodities. In a good economic and policy environment, China's wholesale and retail industry continued to develop and prosper, attracting more capital to enter. As China's opening up to the outside world increased, domestic companies were significantly affected by external shocks. However, the wholesale and retail industry is in a relatively weak position in the supply chain, and the operating pressures in the economic downturn are increasing. Light assets, high leverage, low profit, and short cycle are the characteristics of the wholesale and retail industry. The fixed cost of enterprises is low, the dependence on external financing is strong, and the characteristics of high debt management are obvious.

Due to the current lack of economic growth in China and the sluggish domestic and foreign demand, the wholesale and retail industry that directly connects with consumers will bear the brunt of it. Competition in the wholesale and retail industry is fierce, and the average gross margin level is stable and low. In recent years, the debt ratio of some wholesale and retail companies has increased, which has increased the possibility of credit default. The macro-control of the country, accelerating industrial restructuring, increasing the proportion of the tertiary industry, optimizing the supply chain structure, and stimulating domestic demand are particularly important for the development of the industry. In view of the increasing trend of high non-performing loan ratios in the wholesale and retail trade in recent years, the evaluation of wholesale and retail enterprises by 
banks has become very important. In the case of asymmetric information, it is necessary to grant credits with caution and reasonableness.

\subsection{Real estate industry}

By the end of 2015, the balance of non-performing assets of commercial banks in the real estate industry was 45.59 billion yuan, and the non-performing loan ratio was about $0.81 \%$. The real estate industry has an important influence on China's macroeconomic environment. Its stability is related to the stability of the financial sector and is an important object of the country's macroeconomic regulation and control. The initial investment in the real estate industry is huge, and the payback period is long. Investors usually pursue high returns. Countries frequently introduce restrictions on purchases and loans, and the era of real estate bubbles seems to be heading for the end. This determines that the industry always faces opportunities and challenges. On the one hand, from the perspective of safeguarding people's livelihood and maintaining social stability, China's real estate market is stably improving; on the other hand, due to factors such as policy adjustments and restrictions, and tightness of the real estate industry's own capital chain, commercial banks have set up loans for the real estate industry. The difficulty of judgment is high, and the recovery rate of long-term loans is not easy to control.

\subsection{Transportation, storage and postal services}

As of the end of 2015, the balance of non-performing assets of commercial transport, warehousing and postal services in commercial banks was 33.51 billion yuan, and the non-performing loan ratio was about $0.58 \%$. It remained at a relatively low level or declined, and the risk of repossessing loans was small. It also reflected the The industry is in good condition and it belongs to the high quality industry of bank loans. With the development of China's economy and the improvement of people's living standards, the transportation industry has continued to develop. Driven by the rapid development of "e-commerce", China's logistics industry has developed by leaps and bounds. The Ministry of Commerce issued the "Promotion of the transformation and upgrading of the warehousing industry". "General warehousing will continue to benefit from the support of logistics land policy support and the development of modern warehousing transformation and upgrading. The industry as a whole is improving and has good development potential. Despite the slowdown in the growth of the industry in recent years, the capital pressure on railways and shipping is relatively high, but the overall credit risk of the transportation industry is controllable, and credit quality is at a relatively high level in the industry.

\subsection{Power industry}

As of the end of 2015, the balance of non-performing assets of commercial, power, gas and water production and supply businesses in commercial banks was 11.72 billion yuan, and the non-performing loan ratio was about $0.37 \%$. The power industry has a very large impact on China's economic and social development and the protection of people's livelihood. Although the pace of development of new energy power generation has accelerated in recent years, we have not yet got rid of the current situation of mainly using thermal power generation as the main form of supply, with coal prices rising. The contradiction between coal and electricity has become increasingly prominent, increasing the pressure on the power industry. At present, the development of China's power industry is relatively stable and the credit situation is good. However, in the process of economic restructuring, the energy supply industry is under tremendous pressure. The high debt management of the power generation industry cannot be ignored. The overall risk of the industry is worthy of attention.

\subsection{Public utilities and social security industry}


As the type of industry with the lowest non-performing loan ratio, public utilities or social security industries such as water conservancy, environmental and public facilities management, science, education, health, and social security services generally have certain charity or quasi-public charity characteristics. The project operates in the government. Under the macro-domination, the credit risk is small and the bad loan rate is low, but it may face short-term debt repayment risk. Despite the strong tendency of policy, the growth rate of these industries has also become more rational and stable. However, the credit input of the industry is greatly constrained and is greatly affected by the government's operational control. When the industry is divided, it only accounts for the total bank loans. The lesser part.

Despite the strong tendency of policy, the growth rate of these industries has also become more rational and stable. However, the credit input of the industry is greatly constrained and is greatly affected by the government's operational control which only takes a small part in terms of bank loans.

\section{Conclusion}

In the past six years, the credit risk of China's banks has a strong ability to prevent and control within the industry distribution, and has performed prominently in the manufacturing, wholesale, and retail industries with high non-performing loan ratios. Commercial banks should strengthen the adjustment and optimization of the credit industry structure, fully combine industrial policies and national macro-control policies, combine regional structure and industrial characteristics, limit the loans of potential defaulting enterprises, and improve the bank's operating efficiency with effective credit resource allocation.

\section{References}

[1] Kai WU, Tiegang ZHANG, Wen YANG. Analysis of the Effect of Credit Fluctuation on Capital Structure of Listed Companies: A Research Direction Based on Industry Perspective[J]. Canadian Social Science,2018,14(2).

[2] Bernd Schwaab, Siem Jan Koopman, André Lucas. Global Credit Risk: World, Country and Industry Factors [J]. Journal of Applied Econometrics,2017,32(2).

[3] Dipendra Singh. Credit Availability and Capital Structures: Does Size Matter? An Analysis of the U.S. Lodging Industry[J]. The Journal of Hospitality Financial Management,2016,24(1).

[4] Nader Naifar. Credit Default Sharing Instead of Credit Default Swaps: Toward a More Sustainable Financial System[J]. Journal of Economic Issues,2014,48(1).

[5] Miles Livingston, Winnie P.H. Poon, Lei Zhou. Are Chinese credit ratings relevant? A study of the Chinese bond market and credit rating industry[J]. Journal of Banking and Finance,2018,87.

[6] Mehdi Beyhaghi, Nadia Massoud, Anthony Saunders. Why and how do banks lay off credit risk? The choice between retention, loan sales and credit default swaps[J]. Journal of Corporate Finance, 2017,42 . 